\title{
Adaptation and Validation of the Motivation Scale in Physical Education Classes
}

Boris Milavić1, Mirjana Milić', Damir Jurko' ', Zoran Grgantov ${ }^{1}$ and Kristijan Marić ${ }^{2}$

${ }^{1}$ Faculty of Kinesiology, University of Split

${ }^{2}$ Faculty of Science and Education, University of Mostar

\section{Abstract}

With the purpose of adapting the sport motivation scale (Pelletier, Fortier, Vallerand, Tuscon, Briere, \& Blais, 1995) to the population of students in the final grades of elementary school, that is, with the purpose of measuring their motivation in physical education classes, 305 female and male students of finishing grades were examined. All scales had good metric characteristics, except the unsatisfactory reliability of the external motivation - introjected variable. For both genders, measures of motivation are projected in two components, interpreted as intrinsic motivation, and as amotivation and external regulation. Male students expressed significantly higher values in both scales defining the second factor. The percentage of good and less cumulative grade point average was significantly higher for male students, whereas the percentage of very good and excellent cumulative grade point average was higher for female students. Discriminant analysis has shown that female students with a lower cumulative grade point average (good and satisfactory) were characterized by higher values of external regulation and of amotivation for participating in physical education classes. There were no significant differences found in either gender regarding the motivation in physical education classes in groups differing in their physical education grade point average.

Key words: exercise; external motivation; internal motivation; metric characteristics; students.

\section{Introduction}

Motivation determines the direction of our behavior and its outcome (Deci \& Ryan, 1991). Motivation is also defined as a psychological process of energization which 
influences the individual, but also a poorly comprehended concept in discussion, which makes its conception rather misconstrued in sports as well (Roberts, 1992).

In the context of physical education teaching, motives drive students to certain activities, maintain them and direct students within the activity, but also condition the quality and quantity of the teaching process. There is a difference between a student who actively participates in physical education classes because of his/her own satisfaction and inner need and the one who is driven only by success. The same applies to an athlete's motivation during training. Motivation for participating in physical education classes can also be defined in terms of the influence it causes, directing and maintaining desired behavior in students. Satisfaction with physical education classes is one of the key elements of motivation, thereby a direct and long-term factor of everyday and selfinitiated physical exercise. Horga and Štimac (1999) determined the structure of intrinsic, social and extrinsic reasons for enjoying exercise on a sample of 46 elementary school students. Multivariate discriminant analysis showed statistically significant differences between male and female students in responses to questionnaire items by the two groups. Social and extrinsic reasons for enjoying exercise were isolated in both groups, whereas intrinsic reasons separated into two factors: game excitement and striving for mastery by female students, and challenge and striving for mastery by male students.

Hoffman and Harris (2000) state that there are four basic characteristics of subjective experiences of physical activity: physical activity is always accompanied by a certain level of subjective experiences; subjective experiences are personal and unique; physical activity can be performed even without the deeper understanding of the activity; physical activity will not be meaningful unless we enjoy it. Motivation is often defined as the key element of exerciser's perseverance with the exercise regimen (Wilson \& Rodgers, 2007, according to Vallerand, 2007). According to the social-cognitive approach to achievement motivation, two types of goal modeling in sports can be distinguished: task orientation and ego orientation, which are mutually orthogonal (Barić \& Horga, 2006). For task oriented individuals, success is personal progress in the acquisition and mastering of skills. Ego oriented individuals have an external reference frame for estimating success and they expect a "reward" for their effort: achievement result, being better compared to others as they are highly competitive.

Pelletier, Fortier, Vallerand, Tuscon, Briere and Blais (1995) constructed the Sport Motivation Scale - SMS for measuring three dimensions of sport motivation: intrinsic motivation, extrinsic motivation and amotivation. Intrinsic motivation is measured by three scales: a scale of inner need for knowledge (constructs such as exploration, curiosity, learning goals, motivation for learning, and the epistemic need of knowing and understanding); a scale of need for mastery, accomplishment (a form of intrinsic motivation studied in developmental psychology, as well as in educational research, in terms of mastery motivation, efficacy motivation and task-orientation); and a scale of need for experiencing stimulation (engaging in activity with the goal of experiencing stimulating sensations, for example: sensory pleasure, aesthetic experiences, as well as fun and excitement). External motivation is measured by three scales: a scale of external 
regulation (type of extrinsic motivation corresponding to the one usually found in literature, representing the desire for achieving "external" reward or avoiding negative consequences); a scale of introjection (internalizing a formerly external source of motivation so that behaviors become self-initiated); a scale of identification (the individual uses a system of values to value and judge the behavior as important and, therefore, performs it out of choice; for example, the need of athletes who feel their involvement contributes to a part of their growth and development as a person). The third dimension of sports motivation is amotivation, formerly introduced by the self-determination theory, representing the lack of intrinsic and extrinsic motivation, feeling incompetence and lack of control, making such persons candidates for aborting exercise (Deci \& Ryan, 1985).

Milić, Milavić and Grgantov (2011) found that female and male elementary school students show considerably higher internal motivation than external motivation. They suggest that it is a good predisposition for the school's organised sport activities because such adolescents find more sport satisfaction in skill acquisition and development and increasing personal sport competences, than in expecting, affirming or gaining appraisal from others.

Maršić and Bratanić (2003) established that quality and internal motivation of students were positively related to their attitudes toward the teacher, but also vice versa. Teacher's traits were positively related to the level and quality of students' motivation for his subject. Lorger (2002) investigated motivational processes of higher grade elementary school students during physical education classes. The questionnaire applied had week metric characteristics, especially reliability. Depending on the age, a different number of factors were interpreted, and the only factors reoccurring in students of all grades were exercising for health and excitement.

Maršić, Paradžik and Breslauer (2006) established statistically significant differences between male and female students in motivation for physical education classes. Male students, in relation to female students, had a significantly higher ego-orientation, but there were no significant differences according to gender in students' task orientation. In their research, Cetinić, Polančec and Cimerman (2008) established significant differences regarding intrinsic motivation in students of different profiles of goal orientation. Students with high task orientation, as opposed to students with low task orientation, make more of an effort and give greater importance to physical education classes, have greater interest for exercise and greater enjoyment in classes.

This paper will determine whether it is possible to adapt the sport motivation scale making it applicable for educational purposes, for measuring motivation in physical education classes in the final grades of elementary school.

\section{Methods}

The subject sample consisted of 305 male and female 7th and 8th grade students of elementary schools in Trogir, Kaštela and Solin, without distinct structural deformity which would limit their involvement in sports. Out of 305 participants, 163 were female students, and 142 were male. 
The first set of measured variables included the Sport Motivation Scale (SMS) developed by Pelletier et al. (1995), which assesses motivation for sports, and which was translated by the authors of this paper, adapting the items of the scale for measuring students' motivation for participating in physical education classes. The adapted scale, as well as the original scale, consisted of 28 items asking the question:" Why do you exercise, play or train in physical education classes?" The adapted scale can be found in the appendix of this paper.

Scale items were of a Likert scale type from 1 (I don't agree) to 5 (I fully agree). Four items measured each of the 7 subscales of the scale, motivation dimensions in physical education classes. Three scales measured intrinsic motivation (Intrinsic Motivation to Experience Stimulation, Intrinsic Motivation to Know, Intrinsic Motivation to Accomplish Things), three scales measured extrinsic motivation (Extrinsic Motivation - External Regulation, Extrinsic Motivation - Introjected, Extrinsic Motivation - Identified) and one scale measured amotivation - measure of general intensity of motivation for physical education.

The second set of variables was represented by two measures of school achievement, these being the cumulative grade point average (cumulative GPA) measure and grade point average (GPA) in physical education measure, achieved at the end of the previous school year, given by the subjects before filling out the motivation scale.

The testing procedure was conducted in the final grades of elementary school. A school psychologist or physical education teacher administered the paper-and-pencil type questionnaires. All examinees had written consents from their parents allowing their under-aged child to participate. All school principles received a written request, and replied, also in written form, allowing the testing.

With respect to statistical procedures, procedures for determining basic metric characteristics of adapted scales for measuring motivation in physical education classes were used: reliability - Cronbach alpha; homogeneity - principal component analysis for each subscale of the scale; sensitivity - measures of mean, result range, measure of deviation of results distribution from normal distribution (Kolmogorov-Smirnov test), and measures of symmetry and distribution shape. The results of all subscales were obtained in such a way that the results of all negatively oriented items are recoded into positively oriented items, and then the results of all items of each scale are summed up and divided by the number of items of that scale. By principal component analysis (varimax rotation; Guttman-Kaiser criterion for determining the number of principal components), the latent structure of motivation dimensions of measured adapted scales of motivation in physical education classes was determined. T-test for independent samples was applied to determine the differences between male and female students according to the level of expression of their motivation for physical education. Finally, discriminant analysis was used to determine the differences between student groups of different levels of school achievement (cumulative grade point average and grade point average for physical education) according to their motivation for exercise in physical education classes. 


\section{Results}

Table 1 shows metric characteristics of scales of the SMS questionnaire adapted for physical education classes. A Cronbach alpha coefficient of internal consistency was calculated to assess reliability. To assess homogeneity, items of each scale were projected onto factors, for which the explained variance and its percentage were calculated. Sensitivity was assessed by Kolmogorov-Smirnov test, as well as by analysis of measures of distribution shape. Basic descriptive indicators of the adapted scales (arithmetic mean and standard deviation) were calculated as well.

Table 1

Metric characteristics of the adapted scales of the motivation scale in physical education classes

\begin{tabular}{lcccccccc}
\hline Variable & M & SD & SKEW & KURT & K-S D* & ALPHA & L & $\%$ \\
\hline Amotivation & 2.05 & .92 & .70 & -.32 & .14 & .67 & 2.02 & 50.56 \\
$\begin{array}{l}\text { Intrinsic Motivation to } \\
\text { Experience Stimulation }\end{array}$ & 3.45 & .93 & -.46 & -.33 & .10 & .67 & 2.02 & 50.47 \\
$\begin{array}{l}\text { Intrinsic Motivation } \\
\text { to Know }\end{array}$ & 3.59 & .97 & -.49 & -.30 & .09 & .78 & 2.42 & 60.53 \\
$\begin{array}{l}\text { Intrinsic Motivation to } \\
\text { Accomplish Things }\end{array}$ & 3.69 & .94 & -.52 & -.31 & .10 & .76 & 2.35 & 58.71 \\
$\begin{array}{l}\text { Extrinsic Motivation - } \\
\text { External Regulation }\end{array}$ & 2.81 & .97 & -.04 & -.64 & .06 & .68 & 2.04 & 51.02 \\
$\begin{array}{l}\text { Extrinsic Motivation - } \\
\text { Introjected }\end{array}$ & 3.47 & .86 & -.30 & -.47 & .09 & .58 & 1.78 & 44.34 \\
$\begin{array}{l}\text { Extrinsic Motivation - } \\
\text { Identified }\end{array}$ & 3.42 & .93 & -.32 & -.40 & .08 & .65 & 1.97 & 49.22 \\
\hline
\end{tabular}

* Cut-off value of $\mathrm{K}-\mathrm{S}$ test $\mathrm{D}=1.358 / \sqrt{ } \mathrm{N}=0.078$

LEGEND:

$\mathrm{M}$ - arithmetic mean; SD - standard deviation; SKEW - result of symmetry of results; KURT - results distribution shape result; K-S D - results of Kolmogorov-Smirnov test; CRONBACH ALPHA - coefficient of internal consistency; $\mathrm{L}$ - eigenvalues, characteristic roots; \% - percentage of the explained variance.

As can be seen from Table 1 the reliability of scales varies in the range from .58 for Extrinsic Motivation - Introjected scale to .78 for Intrinsic Motivation to Know scale. In "paper-and-pencil" tests, values of internal consistency coefficients under .60 are considered inadequate. Because of this, Extrinsic Motivation - Introjected scale was excluded from further analysis. Also, it can be observed that all scales were homogenous because their items had projected into a single common latent structure (single factor), and these factors explain $44 \%$ and $60 \%$ of the total variance of the items. According to Kolmogorov-Smirnov (K-S) test, all scales (except Extrinsic Motivation - External Regulation) deviate significantly from a normal distribution. However, it must be noted that K-S test is extremely sensitive to number of subjects and in samples larger than 200, final evaluation of sensitivity of each scale must be done based on analysis of measures of distribution shape. All coefficients of skewness and kurtosis are smaller than 1, therefore, 
parametric statistical procedures can be used in further analyses. Scale means vary from 2.05 for Amotivation variable, which indicates students' motivation for physical education classes, to the highest of 3.69 for Intrinsic Motivation to Accomplish Things variable, which indicates the highest students' motivation in completely mastering certain actions and skills (motor knowledge) which are being practiced and mastered during physical education classes.

\section{Results of Component Analysis}

Table 2 shows the results of factor analysis (principal components method) in variables assessing motivation in physical education classes. Eigenvalues (L) and percentages of the explained variance of the variable set (\%, CUM\%), separately for male and female students, are presented for each component.

Table 2

The principal component analysis of the motivation in physical education classes scale: factor saturation (FS), characteristic roots (L), percentage of the explained variance (\%), cumulative percentage (CUM\%)

\begin{tabular}{lcccc}
\hline \multirow{2}{*}{ Variable } & \multicolumn{2}{c}{ Female Students } & \multicolumn{2}{c}{ Male Students } \\
\cline { 2 - 5 } Amotivation & FS 1 & FS2 & FS 1 & FS 2 \\
$\begin{array}{l}\text { Intrinsic Motivation to } \\
\text { Experience Stimulation }\end{array}$ & -.16 & .91 & -.24 & .85 \\
$\begin{array}{l}\text { Intrinsic Motivation } \\
\text { to Know }\end{array}$ & .88 & -.11 & .86 & .09 \\
$\begin{array}{l}\text { Intrinsic Motivation to } \\
\text { Accomplish Things }\end{array}$ & .88 & -.20 & .90 & -.04 \\
$\begin{array}{l}\text { Extrinsic Motivation - } \\
\text { External Regulation }\end{array}$ & .86 & -.07 & .88 & -.18 \\
$\begin{array}{l}\text { Extrinsic Motivation - } \\
\text { Identified }\end{array}$ & .65 & .54 & .44 & .71 \\
\hline L & .78 & .21 & .80 & .26 \\
\% & 3.34 & 1.22 & 3.22 & 1.34 \\
CUM \% & $56 \%$ & $20 \%$ & $54 \%$ & $22 \%$ \\
\hline
\end{tabular}

LEGEND:

$\mathrm{L}$ - eigenvalues, characteristic roots; \% - percentage of the explained variance; CUM \% - cumulative percentage of the explained variance.

By observing the results of principal component analysis in Table 2, it can be noticed that scales of measures of motivation for participating in physical education classes are projected into two components in the sample of female students as well as in the sample of male students. In both samples, both components explain $76 \%$ of the total variance each, with the first components explaining over 50\%, and the second ones about $20 \%$ of the total variance of the system. Projections of each of the questionnaire scales are also similar in both samples and therefore the extracted factors will be interpreted in the same way for both male and female students. All variables, except amotivation in 
male students, and amotivation and external regulation in female students, had high projections on the first factor. Considering that variables assessing internal motivation had the highest projections, the first factor is interpreted as internal motivation. Due to high projections of scales assessing amotivation and external regulation on the second factor, the factor is interpreted as amotivation and external regulation.

Basic descriptive indicators of variables, as well as analysis of differences in each motivation variable according to gender, are presented in Table 3. Differences according to gender were tested by means of a t-test for independent samples, with associated degrees of freedom and level of significance.

Table 3

Descriptive statistics and significance of differences in motivation according to gender

\begin{tabular}{|c|c|c|c|c|c|c|c|}
\hline \multirow[t]{2}{*}{ Variable } & \multicolumn{2}{|c|}{$\begin{array}{l}\text { Female } \\
\text { Students }\end{array}$} & \multicolumn{2}{|c|}{ Male Students } & \multicolumn{3}{|c|}{ Differences } \\
\hline & $M$ & SD & $M$ & SD & T-TEST & DF & $P$ \\
\hline Amotivation & 1.93 & .85 & 2.18 & .99 & $2.44^{*}$ & 303 & .02 \\
\hline $\begin{array}{l}\text { Intrinsic Motivation to } \\
\text { Experience Stimulation }\end{array}$ & 3.38 & .97 & 3.54 & .88 & 1.48 & 303 & .14 \\
\hline $\begin{array}{l}\text { Intrinsic Motivation } \\
\text { to Know }\end{array}$ & 3.53 & 1.04 & 3.67 & .90 & 1.28 & 303 & .20 \\
\hline $\begin{array}{l}\text { Intrinsic Motivation to } \\
\text { Accomplish Things }\end{array}$ & 3.66 & .97 & 3.71 & .91 & .42 & 303 & .68 \\
\hline $\begin{array}{l}\text { Extrinsic Motivation - } \\
\text { External Regulation }\end{array}$ & 2.59 & .98 & 3.07 & .89 & $4.41^{* *}$ & 303 & .00 \\
\hline $\begin{array}{l}\text { Extrinsic Motivation - } \\
\text { Identified }\end{array}$ & 3.38 & .97 & 3.46 & .88 & 0.76 & 303 & .45 \\
\hline
\end{tabular}

LEGEND:

$\mathrm{M}$ - arithmetic mean; SD - standard deviation; T-TEST - $t$-test coefficient; $\mathrm{DF}$ - degrees of freedom; $\mathrm{p}=$ significance level of the t-test coefficient; ${ }^{*}$ - statistical significance of coefficients at the level of $p<.05$; ${ }^{* *}$ - statistical significance of coefficients at the level of $p<.01$.

Based on the analysis of descriptive indicators, it can be inferred that subjects in both samples achieved highest scores in 3 scales assessing internal motivation, somewhat lower values in scales assessing external motivation, and the lowest in the scale assessing amotivation. Significance of differences according to gender was analyzed using a t-test. There were significant differences found in only 2 variables on the common factor of amotivation and external regulation. Male students had significantly higher values on both scales defining that factor. There were no differences between male and female students in either measure assessing internal motivation in physical education classes.

In Table 4, male and female students were divided into 3 groups according to their cumulative grade point average and grade point average in physical education. Significance of frequency of cumulative grade point average and grade point average in physical education for each gender group was analyzed by a $\chi 2$-test. 
Milavić, Milić, Jurko, Grgantov and Marić: Adaptation and Validation of the Motivation Scale ...

Table 4

Frequency of cumulative grade point average and grade point average in physical education in female and male students

\begin{tabular}{|c|c|c|c|c|c|c|c|}
\hline \multirow{2}{*}{ Groups } & & \multicolumn{2}{|c|}{ Female Students } & \multicolumn{2}{|c|}{ Male Students } & \multirow{2}{*}{$\begin{array}{c}\text { Total } \\
\text { Frequency }\end{array}$} & \multirow{2}{*}{$\begin{array}{c}\text { Differences } \\
\text { of } \%\end{array}$} \\
\hline & & Frequency & $\%$ & Frequency & $\%$ & & \\
\hline \multirow{3}{*}{$\begin{array}{l}\text { Cumulative } \\
\text { Grade } \\
\text { Point } \\
\text { Average }\end{array}$} & $\begin{array}{l}\text { Good } \\
\text { and Less }\end{array}$ & 24 & 14.72 & 44 & 30.99 & 71 & \multirow{3}{*}{$\begin{array}{c}X 2=12.38^{* *} \\
P=.002\end{array}$} \\
\hline & $\begin{array}{l}\text { Very } \\
\text { Good }\end{array}$ & 70 & 42.94 & 50 & 35.21 & 120 & \\
\hline & Excellent & 69 & 42.33 & 48 & 33.80 & 117 & \\
\hline \multirow{3}{*}{$\begin{array}{l}\text { Grade } \\
\text { Point } \\
\text { Average } \\
\text { in Physical } \\
\text { Education }\end{array}$} & $\begin{array}{l}\text { Good } \\
\text { and Less }\end{array}$ & 10 & 6.13 & 7 & 4.93 & 17 & \multirow{3}{*}{$\begin{array}{c}X 2=1.82 \\
P=.40\end{array}$} \\
\hline & $\begin{array}{l}\text { Very } \\
\text { Good }\end{array}$ & 29 & 17.79 & 33 & 23.24 & 62 & \\
\hline & Excellent & 124 & 76.07 & 102 & 71.83 & 226 & \\
\hline
\end{tabular}

LEGEND:

$X 2-X 2$-test; $P=$ level of significance of $X 2$-test coefficients; ${ }^{* *}$-statistical significance of coefficients at the level of $\mathrm{p}<.01$.

Based on the results in Table 4, it can be inferred that male and female students differ significantly in the percentage of frequency of their academic achievement, namely in the measure of cumulative grade point average. The percentage of students with good and satisfactory cumulative grade point average is significantly higher for male students, whereas the percentage of students with very good and excellent cumulative grade point average is higher for female students.

As opposed to the criterion of cumulative grade point average, male and female students do not express significant differences in the frequency of grade point average in physical education. Because of these findings, as well as the determined differences in values of measures of motivation in physical education classes, in further analysis, the discriminant analysis was calculated separately for male and female samples. This way, the possibility of attributing the determined differences of motivation in physical education classes to gender differences is excluded.

\section{Results of Discriminant Analysis}

Results of discriminant analysis of male and female students with different cumulative grade point average and different grade point average in physical education are presented in Tables 5 and 6. Eigenvalue of discriminant function $(\lambda)$, coefficient of canonical correlation (Rc) and Wilks' lambda coefficient (W $\lambda$ ) were calculated. The $\chi^{2}$-test was used to test the significance of the discriminant function with associated degrees of freedom. Group centroids were also calculated for both groups, as well as projections of each scale on discriminant function (matrix structure). For each calculated discriminant analysis, only the first discriminant function was shown in each table because the second discriminant function was not statistically significant in any of the analyses. 
Table 5

Discriminant analysis in a sample of female students with different cumulative grade point average

\begin{tabular}{|c|c|c|c|c|c|c|}
\hline DFN & $\lambda$ & $R c$ & Wilks'lambda & $x^{2}$ & DF & $P=$ \\
\hline 1 & .14 & .35 & .85 & $25.44^{*}$ & 12 & .013 \\
\hline
\end{tabular}

Table 6

Matrix structure and group centroids in the sample of female students with different cumulative grade point average

\begin{tabular}{lc}
\hline Variable & Structure matrix \\
\cline { 2 - 2 } & DFN 1 \\
\hline Amotivation & -.60 \\
Intrinsic Motivation to & -.20 \\
Experience Stimulation & \\
Intrinsic Motivation & -11 \\
to Know & \\
Intrinsic Motivation to & .03 \\
Accomplish Things & \\
Extrinsic Motivation - & -.73 \\
External Regulation & \\
Extrinsic Motivation - & -.17 \\
Identified & Group Centroids \\
\hline Cumulative Grade Point & DFN 1 \\
Average & -.51 \\
\hline Good and Less & -.24 \\
Very Good & .42 \\
Excellent &
\end{tabular}

Legend:

DFN - discriminant function.

Table 7

Discriminant analysis in a sample of male students with different cumulative grade point average

\begin{tabular}{lcccccc}
\hline DFN & $\lambda$ & $R c$ & Wilks'lambda & $X^{2}$ & DF & $P=$ \\
\hline 1 & .11 & .32 & .89 & 15.87 & 12 & .20 \\
\hline
\end{tabular}

LEGEND:

DFN - discriminant function; $\lambda$ - Eigenvalue of discriminant function; Rc-coefficient of canonical correlation; Wilks'lambda - Wilks'lambda coefficient (W $\lambda$ ) of discriminant function; $X^{2}$ - test of significance of discriminant function $-X^{2}$ test; ${ }^{*}$ - level of statistical significance of $D F$ of $p<.05 ; D F$ - degrees of freedom; $P$ - level of statistical significance of $X^{2}$-test. 
Table 8

Matrix structure and group centroids in the sample of male students with different cumulative grade point average

\begin{tabular}{lc}
\hline \multirow{2}{*}{ Variable } & Structure matrix \\
\cline { 2 - 2 } Amotivation & DFN 1 \\
Intrinsic Motivation to & -.73 \\
Experience Stimulation & .28 \\
Intrinsic Motivation \\
to Know \\
Intrinsic Motivation to \\
Accomplish Things \\
Extrinsic Motivation - \\
$\begin{array}{l}\text { External Regulation } \\
\text { Extrinsic Motivation - }\end{array}$ \\
Identified \\
\hline $\begin{array}{l}\text { Cumulative Grade Point Average } \\
\text { Good and Less }\end{array}$ \\
Very Good & .21 \\
Excellent & -.60 \\
\hline Legend: & -.03 \\
DFN - discriminant function. & DFN 1 \\
\end{tabular}

Table 9

Discriminant analysis in a sample of female students with different grade point average in physical education

\begin{tabular}{|c|c|c|c|c|c|c|}
\hline DFN & $\lambda$ & $R c$ & Wilks' lambda & $x^{2}$ & DF & $\mathrm{P}=$ \\
\hline 1 & .04 & .20 & .93 & 11.72 & 12 & .47 \\
\hline \multicolumn{7}{|c|}{$\begin{array}{l}\text { LEGENDA: } \\
\text { DFN - discriminant function; } \lambda \text { - Eigenvalue of discriminant function; Rc - } \\
\text { coefficient of canonical correlation; Wilks' lambda - Wilks' lambda coefficient (W }) \text { ) } \\
\text { of discriminant function; } \chi^{2} \text { - test of significance of discriminant function }-\chi^{2} \text { test; * } \\
\text { - level of statistical significance of DF of } p<.05 ; D F \text { - degrees of freedom; } P \text { - level of } \\
\text { statistical significance of } \chi^{2} \text {-test. }\end{array}$} \\
\hline
\end{tabular}


Table 10

Matrix structure and group centroids in a sample of female students with different grade point average in physical education

\begin{tabular}{lc}
\hline \multirow{2}{*}{ Variable } & Structure matrix \\
\cline { 2 - 2 } & DFN 1 \\
\hline Amotivation & -.78 \\
Intrinsic Motivation to & .55 \\
$\begin{array}{l}\text { Experience Stimulation } \\
\text { Intrinsic Motivation }\end{array}$ & \\
to Know & .38 \\
$\begin{array}{l}\text { Intrinsic Motivation to } \\
\text { Accomplish Things }\end{array}$ & .55 \\
Extrinsic Motivation - \\
$\begin{array}{l}\text { External Regulation } \\
\text { Extrinsic Motivation - } \\
\text { Identified }\end{array}$ \\
\hline $\begin{array}{l}\text { Grade Point Average in Physical } \\
\text { Education }\end{array}$ & -.08 \\
\hline $\begin{array}{l}\text { Good and Less } \\
\text { Very Good }\end{array}$ & .10 \\
Excellent & Group Centroids \\
\hline
\end{tabular}

LEGEND:

DFN - discriminant function.

Table 11

Discriminant analysis in a sample of male students with different grade point average in physical education

\begin{tabular}{lcccccc}
\hline DFN & $\lambda$ & $R c$ & Wilks'lambda & $X^{2}$ & DF & $P=$ \\
\hline 1 & .08 & .28 & .91 & 12.37 & 12 & .42
\end{tabular}

LEGEND:

DFN - discriminant function; $\lambda$ - Eigenvalue of discriminant function; Rc - coefficient of canonical correlation; Wilks' lambda - Wilks' lambda coefficient $(W \lambda)$ of discriminant function; $\chi^{2}$ - test of significance of discriminant function $-X^{2}$ test; ${ }^{*}$ - level of statistical significance of DF of $p<.05 ; D F-$ degrees of freedom; $P$ - level of statistical significance of $X^{2}$-test. 
Table 12

\begin{tabular}{|c|c|}
\hline \multirow{2}{*}{ Variable } & Structure matrix \\
\hline & DFN 1 \\
\hline Amotivation & -.67 \\
\hline $\begin{array}{l}\text { Intrinsic Motivation to } \\
\text { Experience Stimulation }\end{array}$ & .70 \\
\hline $\begin{array}{l}\text { Intrinsic Motivation } \\
\text { to Know }\end{array}$ & .57 \\
\hline $\begin{array}{l}\text { Intrinsic Motivation to } \\
\text { Accomplish Things }\end{array}$ & .50 \\
\hline $\begin{array}{l}\text { Extrinsic Motivation - } \\
\text { External Regulation }\end{array}$ & .03 \\
\hline $\begin{array}{l}\text { Extrinsic Motivation - } \\
\text { Identified }\end{array}$ & .56 \\
\hline \multirow{2}{*}{$\begin{array}{l}\text { Grade Point Average in } \\
\text { Physical Education }\end{array}$} & Group Centroids \\
\hline & DFN 1 \\
\hline Good and Less & -.61 \\
\hline Very Good & -.42 \\
\hline Excellent & .18 \\
\hline
\end{tabular}

It can be seen from Tables 5-8 that significant differences in motivation for physical education classes were obtained among female students with a different cumulative grade point average, but not in male students. The structure of the discriminant function and values of group centroids indicate that female students with lower cumulative grade point average (good and satisfactory and partly very good) were characterized by higher values of external regulation and higher values of amotivation in physical education classes. Discriminant analysis showed no differences in motivation for physical education classes in groups with different grade point average in physical education, either in males or females (from Tables 9-12).

\section{Discussion and Conclusion}

Metric characteristics of questionnaire scales (homogeneity, reliability and sensitivity) adapted for measuring motivation in class were good, except the introjection scale. The introjection scale had an inadequate level of significance, which was expected. Namely, authors of the SMS questionnaire (Pelletier et al., 1995) state that previous external (extrinsic) motivational reasons for participation in sport "change" during long-term exercising by a procedure of introjection and become internal (intrinsic) motivational reasons. It would be reasonable to assume that among students in final grades of elementary school, due to the insufficient period of involvement in exercise, the introjection procedure of probable extrinsic motivational reasons for exercising has not been completely finished, but was still in process. Thus, items of introjection type, 
assessing external motivation in physical education classes, cannot reach the adequate level for measuring external motivation. Therefore, except for introjection of external motivation, all constructs of sport motivation are, with certain adjustment, applicable for measuring motivation in physical education classes.

Latent structure of motivation in physical education classes determined on separate samples of male and female students differs from the model (Pelletier et al., 1995) which suggests the existence of three dimensions of sport motivation. The difference is expressed in the fact that most of the measuring variables of motivation in physical education classes are projected in the internal motivation factor, while amotivation and external regulation were "merged" into one common factor. External motivation might not be differentiated into a separate dimension of motivation in psychical education classes as opposed to sport motivation, because there are fewer opportunities and possibilities in physical education classes for extrinsic influence on the exercise participant. Groups of exercisers are larger in classes than in sports and the number of exercise hours are fewer, teachers are not as oriented towards sport achievement of exercisers as coaches are, there is no competition which exists in almost every sport, etc. Amotivation has the lowest values of all measuring variables both in male and female students, which indicates students' motivation for exercising in physical education classes. External regulation (i.e. what is generally and usually considered external motivation) has the lowest values both in male and female students compared to all other measures of extrinsic and intrinsic motivation in physical education classes. Measures of internal motivation are higher in relation to this measure of external motivation. Differences between male and female students are determined in amotivation and external regulation variables, a separate dimension of motivation in physical education classes, which confirms the findings of Maršić et al. (2006) that there were no differences found between male and female students in intrinsic motivation, but there were differences found in extrinsic motivation. Male students express higher values of amotivation, but also higher values of external regulation as opposed to female students, which again confirms findings of Maršić et al. (2006).

For both male and female students, the rank order of measures of motivation in physical education classes is very similar. In both samples, a need for mastering measure of motivation had the highest values, which indicates internal motivation of students in the final grades of elementary school and their "openness" for the acquisition of new contents in physical education classes.

Measures of internal motivation had higher values than measures of external motivation in physical education classes in both subject samples. This finding about the differences in the level of expression of internal and external motivation in the subject of physical education raises the idea (notion) of the existence of large quantity of "reserves" for externally motivating students for exercising in physical education classes, as well as the necessity for these "motivational" reserves yet being developed and utilized by additional training of physical education teachers. 
The obtained results about the differences of one form of academic achievement (cumulative grade point average) indicate that female students have higher motivation for achieving success in education. Distributions of both measures of academic achievement were asymmetric. Also, in both samples, grade point average in physical education showed extremely negative asymmetry, and compared to cumulative grade point average of the same samples, had significantly larger percentage of those with high grades. Observed differences in two measures of academic achievement can be attributed to a number of reasons:

- cumulative grade point average represents a categorized average of grades in all subjects;

- the subject of physical education is unfortunately often used in practice as a subject for raising the average and thus "improving" the cumulative grade point average;

- the subject of physical education is graded "stimulatingly" in teaching practice so, even if an individual does not possess adequate motor abilities, but has adopted the motor knowledge and participates equally in all contents, and is active in physical education classes, he/she can earn a high "stimulative" grade;

- measures of cumulative grade point average are usually used as a criterion for high school admission, and physical education is not used for this purpose, so it is likely that achievement in this subject is "free" from evaluation pressure.

Regardless of the reasons for noticeable differences between two measures of academic achievement, these findings additionally hinder the validation of the scale for measuring motivation in physical education classes.

The significance of differences in motivation for physical education that has been established on a sample of female students indicates that female students with lower cumulative grade point average express higher values of amotivation and external regulation. Groups of students of different cumulative grade point average differ very little in their internal motivation. Reasons for this could be different, e.g. correlation of low motivation among female students for achieving a better cumulative grade point average with low motivation for achieving a better grade point average in the subject of physical education. Moreover, such students seek much more external motivational stimuli and attention from the teacher for their effort in physical education classes, and if they do not obtain it, they feel amotivated for greater engagement. The inability to recognize students' amotivation because of teaching responsibilities or inadequate education of some physical education teachers can also be one of the reasons.

On the other hand, more successful female students are usually more motivated, confident about their abilities and competences, persistent in solving and mastering the tasks, and therefore express a lower level of amotivation and external motivation in physical education classes. In the sample of male students, there were no differences found in motivation for physical education classes in groups of students of different cumulative grade point average. 
These findings about the determined significance of differences in motivation among female students, and the lack of motivation among male students, should be related to previously determined differences between male and female students precisely in measures of amotivation and external regulation. By connecting these two findings, it is possible to compare the determined structure of motivation for physical education classes among female students with lower cumulative grade point average to the similar motivational structure expressed by male students.

Discriminant analysis has shown differences in the level of motivation in physical education classes neither among female students nor among male students of different grade point average in physical education. The lack of significant differences in motivation can justifiably be attributed to the structure of distribution of grade point average in the physical education subject, which is not discriminant because there is a very large percentage of male and female students who have the highest grade in this subject, over $70 \%$ in both groups.

In order to validate the adapted scale for measuring motivation in physical education in a quality manner, it is recommended to do further research on the following: firstly, to increase the number of subjects, both in male and female sample, in order to allow generalization; secondly, to include a variable of students' organized participation in sports into the research, as well as variable of kinesiological engagement and perceived sports competence - because it is possible that students "transfer" their higher external regulation from their organized sports involvement or a higher level of their kinesiological engagement; and thirdly, to correlate the results of motivation in male and female students with the conditions in which the physical education classes occur - for example, is there a possibility of using the gym, etc. Finally, motivation in physical education classes would probably be expressed or structured differently if the number of physical education classes was increased, which would allow a better acquisition of motor knowledge, and thereby increase the teacher's responsibility for motivating students in physical education classes.

Finally, it can be inferred that the adapted scale for measuring motivation in physical education classes has good metric characteristics, except for the external motivation - introjected scale which was excluded from further analysis. The questionnaire measures two latent dimensions of motivation: internal motivation and amotivation/ external regulation. Measures of internal motivation were significantly higher that amotivation/external regulation in both samples. Male students express significantly higher amotivation and external regulation than female students.

In the sample of female students, students of different cumulative grade point average differ significantly in the set of motivation measures, particularly in the amotivation/ external regulation dimension. No significant relations were found between grade point average in physical education and the set of motivation variables. It is estimated that the adapted scale is a quality instrument which needs further validation in future research by using additional items and a larger subject sample. By applying this questionnaire, 
physical education teachers can achieve multiple goals: first, to measure the state of motivation in physical education classes in each grade at the time of application and compare it to the results of students in this study or similar studies; second, to measure possible changes in motivation of student grades in physical education classes between the initial and final measuring which can occur due to different material working conditions, different personal engagement of physical education teachers in the immediate teaching process during the academic year, and changes in the level of kinesiological engagement of students in extracurricular activities. Also, it is recommended that physical education teachers give more consideration to quality communication with students in the final grades of elementary school, and thereby to an enhanced influence of students' external motivation on performance in physical education classes.

\section{References}

Barić R., \& Horga, S. (2006). Psychometric properties of the Croatian version of Task and Ego Orientation in Sport Questionnaire (CTEOSQ). Kinesiology, 38(2), 135-142.

Cetinić, J., Polančec, J., \& Cimerman, M. (2008). Profiles of goal orientation in physical education classes: differences in the factors of intrinsic motivation (In Croatian). In B. Neljak (Ed.), 17. ljetna škola kineziologa Hrvatske, Poreč, (pp. 101-106). Zagreb: Hrvatski kineziološki savez.

Deci, E. L., \& Ryan, R. M. (1985). Intrinsic motivation and self-determination in human behavior. New York: Plenum Press. http://dx.doi.org/10.1007/978-1-4899-2271-7

Deci, E. L., \& Ryan, R. M. (1991). A motivational approach to self: Integration in personality. In R. Dienstbier (Ed.), Nebraska Symposium on motivation: Perspectives on motivation (Vol. 38, pp. 237-288). Lincoln, NE: University of Nebraska Press.

Hoffman, S., \& Harris, J. C. (2000). Introduction to Kinesiology - studying physical activity. Champaign, IL: Human Kinetics.

Horga, S., \& Štimac, D. (1999). Why do children exercise? Evaluation of one motivational scale (In Croatian). Kinesiology (0351-1057), 31(1), 57-63.

Lorger, M. (2002). Motivation factors and differences in the motivation of girls in primary schools in the teaching of physical education classes (Master's Thesis, Faculty of Kinesiology) - (In Croatian). Zagreb: Faculty of Kinesiology, University of Zagreb.

Maršić, T., \& Bratanić, M. (2003). Possibility of defining the quality of student-teacher relationships using some indicators of pupils' views (In Croatian). In V. Findak (Ed.), 12. ljetna škola kineziologa Hrvatske, Poreč, (pp. 77-81). Zagreb: Hrvatski kineziološki savez.

Maršić, T., Paradžik, P., \& Breslauer, N. (2006). Gender differences in motivation of physical education classes (In Croatian). Napredak, 147(3), 328-334. 
Milić, M., Milavić, B., \& Grgantov, Z. (2011). Relations between sport involvement, selfesteem, sport motivation and types of computer usage in adolescents. In S. Simović (Ed.), Proceedings of 3rd International Scientific Congress "Anthropological Aspects of Sport, Physical Education and Recreation". November 2011. Banja Luka: University of Banja Luka, Faculty of Physical Education and Sport (in press).

Pelletier, L. G., Fortier, M. S., Vallerand, R. J., Tuscon, K. M., Briere, N. M., \& Blais, M. R. (1995). Toward a new measure of intrinsic motivation, extrinsic motivation, and amotivation in sports: The Sport Motivation Scale. Journal of Sport and Exercise Psychology, 17, 35-53.

Roberts, G. C. (1992). Motivation in sport and exercise: Conceptual constraints and convergence. In G. C. Roberts (Ed.), Motivation in sport and exercise (pp. 3-30). Champaign, IL: Human Kinetics.

Vallerand, R. J. (2007). Intrinsic and Extrinsic Motivation in Sport and Physical Activity. In G. Tenenbaum \& R. C. Eklund (Eds.), Handbook of Sport Psychology (pp. 59-80). Hoboken, NJ: John Wiley \& Sons, Inc.

\section{Boris Milavić}

Faculty of Kinesiology, University of Split

Teslina 6, 21000 Split, Croatia

boris.milavic@gmail.com

\section{Mirjana Milić}

Faculty of Kinesiology, University of Split

Teslina 6, 21000 Split, Croatia

mirjanam@net.hr

\section{Damir Jurko}

Faculty of Kinesiology, University of Split

Teslina 6, 21000 Split, Croatia

dama1j@yahoo.com

\section{Zoran Grgantov}

Faculty of Kinesiology, University of Split

Teslina 6, 21000 Split, Croatia

grga@kifst.hr

\section{Kristijan Marić}

Faculty of Science and Education, University of Mostar

Ulica Matice hrvatske b.b., 88000 Mostar, Bosnia and Herzegovina

marickristijan@yahoo.com 


\section{Adaptacija i validacija upitnika motivacije u nastavi Tjelesne i zdravstvene kulture}

\section{Sažetak}

$S$ ciljem prilagodbe upitnika motivacije za sport (Pelletier, Fortier, Vallerand, Tuscon, Briere i Blais, 1995) populaciji završnih razreda osnovne škole, odnosno s ciljem mjerenja njihove motivacije u nastavi Tjelesne i zdravstvene kulture, 305 učenica i učenika završnih razreda osnovnih škola popunilo je prilagođeni upitnik. Sve ljestvice imaju dobre mjerne karakteristike, osim nezadovoljavajuće pouzdanosti varijable eksternalne motivacije - introjicirane. U oba spola mjere motivacije za izvedbu nastave Tjelesne i zdravstvene kulture projiciraju se u dvije komponente interpretirane kao unutrašnja motivacija, amotivacija i eksternalna regulacija. Učenici imaju značajno više vrijednosti u obje ljestvice koje definiraju drugi faktor. Kod učenika je znatno veći postotak općeg uspjeha dobar i manji, a kod učenica je veći postotak vrlo dobrog i izvrsnog općeg uspjeha. Diskriminacijska analiza pokazala je kako učenice s nižim općim uspjehom (dobar i manji) karakterizira viša izraženost eksternalne regulacije i više izražena amotiviranost u izvedbi nastave tjelesne i zdravstvene kulture. $U$ oba spola nisu dobivene razlike u motivaciju u nastavi tjelesne i zdravstvene kulture kod skupina različitih po uspjehu iz nastavnog predmeta Tjelesne i zdravstvene kulture.

Ključne riječi: eksternalna motivacija, internalna motivacija, mjerne karakteristike, učenici, vježbanje.

\section{Uvod}

Motivacija određuje smjer našeg ponašanja i njezin završetak (Deci i Ryan, 1991). Motivacija je također definirana kao psihološki proces energičnosti koji utječe na pojedinca, ali je ujedno i oskudno shvaćen fenomen u raspravi te je tako njezina koncepcija dosta neshvaćena i u sportu (Roberts, 1992).

U kontekstu nastavnog procesa Tjelesne i zdravstvene kulture motivi pokreću učenike na određenu aktivnost, održavaju ih, te usmjeravaju u toj aktivnosti, ali ujedno i uvjetuju kvalitetu i kvantitetu rezultata nastavnog procesa. Nije svejedno je li učenik aktivan na satu TZK-a zbog vlastitog zadovoljstva i unutarnje potrebe ili zbog ocjene, kao i to je li sportaš motiviran na treningu radi zadovoljstva ili uspjeha. Ujedno, motivacija za 
izvedbu nastave TZK može se definirati i kao utjecaj koji izaziva, usmjerava i održava željeno ponašanje učenika. Zadovoljstvo nastavom TZK jedna je od ključnih sastavnica motivacije, a time i izravni i dugoročni čimbenik svakodnevnog i samostalnog tjelesnog vježbanja. Horga i Štimac (1999) utvrđivali su strukturu intrinzičnih, socijalnih i ekstrinzičnih razloga uživanja u vježbanju na uzorku od 46 učenika osnovne škole. Multivarijatna diskriminacijska analiza pokazala je statistički značajne razlike po spolu u odgovorima dviju skupina na čestice upitnika. I u jednih i u drugih izolirani su socijalni i ekstrinzični razlozi uživanja u vježbanju, a intrinzični su se razdvojili u dva faktora, i to u uzbuđenje igre i težnji za majstorstvom u djevojčica, a izazovu i težnji za majstorstvom u dječaka.

Hoffman i Harris (2000) navode kako postoje četiri osnovne značajke subjektivnog iskustva tjelesne aktivnosti: tjelesnu aktivnost uvijek prati određeni subjektivni doživljaj; subjektivni je doživljaj osoban i jedinstven; tjelesnu aktivnost možemo izvoditi i bez razumijevanja aktivnosti; sama tjelesna aktivnost gubi značaj ako nam ne predstavlja zadovoljstvo. Motivacija se učestalo definira kao ključni element ustrajnosti vježbača unutar područja vježbanja (Wilson i Rodgers, 2007, prema Vallerand, 2007). Prema socijalno-kognitivnom pristupu motivaciji postignuća razlikujemo dva načina modeliranja ciljeva u sportu: usmjerenost na zadatak (task orijentacija) i usmjerenost na ishod (ego orijentacija) koji su ortogonalni u odnosu jedan na drugog (Barić i Horga, 2006). Pojedincu usmjerenom na zadatak uspjeh je osobno napredovanje u usvajanju i savladavanju vještina. Pojedinac usmjeren na ishod ima izvanjski referentni okvir za procjenu uspjeha te očekuje „nagradu” za uloženi rad: rezultatsko postignuće, biti bolji u odnosu na druge, zbog čega je izrazito kompetitivan.

Pelletier, Fortier, Vallerand, Tuscon, Briere i Blais (1995) konstruirali su Upitnik sportske motivacije (Sport Motivation Scale - SMS) kojim se mjere tri dimenzije motivacije za sport: intrinzična motivacija, ekstrinzična motivacija i amotivacija. Intrinzična motivacija mjeri se trima ljestvicama: ljestvicom unutarnje potrebe za znanjem (konstrukti poput istraživanja, radoznalosti, ciljeva učenja, motivacije za učeje, kao i epistemičke potrebe znati i razumjeti); ljestvicom potrebe za savladavanjem, ostvarivanjem [oblik unutarnje motivacije proučavan u razvojnoj psihologiji, kao i u edukacijskim istraživanjima, pod izrazima motivacija savladavanja (engl.: mastery motivation), motivacija učinkovitosti (engl.: efficacy motivation) i orijentacija na zadatak (engl.: task-orientation)]; zatim ljestvicom potrebe za iskušavanjem stimulacije (angažiranje u aktivnosti kako bi se iskusile stimulirajuće senzacije, primjerice osjetilno zadovoljstvo, estetska iskustva, zabava i uzbuđenje). Eksternalna motivacija mjeri se trima ljestvicama: ljestvicom eksternalne regulacije (oblik ekstrinzične motivacije koji odgovara onom obliku kakav se općenito nalazi u literaturi, a predstavlja želju za ostvarivanjem „izvanjske” nagrade ili izbjegavanje kazne); ljestvicom introjekcije (kojom su prijašnji eksternalni izvori motivacije postali unutarnji, a ponašanja se potom sama iniciraju); ljestvicom identifikacije (pojedinac se koristi sustavom vrijednosti kako bi vrednovao i prosudio neko ponašanje kao važno, pa ga stoga izvodi obvezatno i bez izbora, primjerice potreba 
sportaša koji osjećaju kako njihova uključenost djelomično doprinosi osobnom rastu i razvoju). Treća dimenzija motivacije za sport je amotivacija, prethodno predložena teorijom samodeterminacije, a koja predstavlja nedostatak intrinzične i ekstrinzične motivacije, osjećanje nekompetentnosti i nemogućnosti kontrole, te su takve osobe kandidati za odustajanje od vježbanja (Deci i Ryan, 1985).

Milić, Milavić i Grgantov (2011) utvrdili su kako učenici završnih razreda osnovnih škola imaju zamjetno izraženiju unutrašnju motivaciju za sport nego eksternalnu motivaciju za sport. Navode kako to predstavlja dobru predispoziciju za organizirano bavljenje sportom jer takvi adolescenti zadovoljstvo u sportu više nalaze u usvajanju i razvoju vještina te povećavanju osobnih sportskih kompetencija nego u očekivanju, potvrđivanju ili dobivanju nagrade od drugih.

Maršić i Bratanić (2003) su utvrdili kako je kvaliteta i unutarnja motiviranost učenika pozitivno povezana s njihovim stavovima prema nastavniku, ali i obrnuto. Osobine nastavnika pozitivno su povezane s visinom i kvalitetom motiviranosti učenika za nastavni predmet koji predaje. Lorger (2002) je istraživala motivacijske procese učenika viših razreda osnovne škole tijekom nastave tjelesne i zdravstvene kulture. Primijenjeni upitnik imao je slaba metrijska svojstva, posebno pouzdanost. Ovisno o dobi interpretiran je i različit broj faktora, a jedini faktori koji se ponavljaju kod učenika svih razreda su vježbanje zbog zdravlja i uzbuđenja.

Maršić, Paradžik i Breslauer (2006) su utvrdili postojanje statistički značajne razlike među spolovima u motivaciji za nastavni predmet tjelesna i zdravstvena kultura. Učenici su u odnosu na učenice značajno više egoorijentirani, a u orijentaciji učenika na svladavanje zadataka nema bitnih razlika među spolovima. Cetinić, Polančec i Cimerman (2008) su istraživanjem utvrdili kako postoje značajne razlike u intrinzičnoj motivaciji kod učenika različitih profila ciljne orijentiranosti. Učenici visoke usmjerenosti na zadatak razlikuju se od nisko usmjerenih učenika na zadatak po većem uloženom naporu i većem pridavanju važnosti nastavi tjelesne i zdravstvene kulture, kao i većem interesu za vježbanje i većem uživanju na satovima.

U ovom će radu biti utvrđeno je li moguće upitnik motivacije za sport prilagoditi za primjenu u edukacijske svrhe, za mjerenje motivacije u nastavi Tjelesne i zdravstvene kulture završnih razreda osnovnih škola.

\section{Metode}

Uzorak ispitanika sastavljen je od 305 učenica i učenika 7.i 8. razreda osnovnih škola gradova Trogira, Kaštela i Solina, bez izraženog strukturalnog deformiteta koji bi limitirao njihovo bavljenje sportom. Od toga su bile 163 učenice i 142 učenika.

Prvi skup mjerenih varijabli sačinjavao je Upitnik sportske motivacije (SMS) autora Pelletier i sur. (1995) kojim se ispituje motivacija za sport, a koji su autori rada preveli i prilagodili čestice za mjerenje motivacije učenika za izvođenje nastave Tjelesne i zdravstvene kulture. Adaptirani upitnik se kao i izvorni upitnik sastoji se od 28 čestica u kojima se odgovara na postavljeno pitanje: „Zašto vježbaš, igraš se ili treniraš na nastavi 
Tjelesne i zdravstvene kulture?’. Primjeri čestica koje su korištene u adaptiranom upitniku su: „Zbog uzbuđujućih iskustava koja doživljavam.“, „Kako bi pokazao drugima koliko sam dobar u onome što vježbam.“, „Zbog zadovoljstva koje osjećam dok izvodim neke teške elemente (kretnje).“, „Zbog zadovoljstva pri otkrivanju novih strategija igre i vježbanja.“ $i$ „Zbog zadovoljstva koje osjetim kad poboljšam neku svoju slabu točku?“ Cijeli adaptirani upitnik nalazi se u prilogu radu.

Čestice upitnika su Likertova tipa s mjernom ljestvicom od 1 (ne slažem se) do 5 (potpuno se slažem). Po četiri čestice mjere svaku od 7 subljestvica upitnika, dimenzija motivacije u nastavi tjelesne i zdravstvene kulture. Tri ljestvice mjere intrinzičnu motivaciju (intrinzična motivacija - iskusiti stimulaciju, intrinzična motivacija - spoznati, intrinzična motivacija - ostvariti), tri ljestvice mjere ekstrinzičnu motivaciju (ekstrinzična motivacija - eksternalna regulacija, ekstrinzična motivacija - introjicirana, ekstrinzična motivacija - identificirana) i jedna ljestvica mjeri amotivaciju - mjeru općeg intenziteta motivacije za nastavni predmet Tjelesne i zdravstvene kulture.

Drugi skup varijabli predstavljaju dvije mjere školskog postignuća i to mjere općeg uspjeha i mjera uspjeha u nastavnom predmetu Tjelesne i zdravstvene kulture, ostvarene na kraju protekle školske godine, a o čemu su ispitanici izvijestili prije ispunjavanja upitnika motivacije.

Postupak ispitivanja proveden je u prostorijama završnih razreda osnovnih škola. Školski psiholog ili profesor Tjelesne i zdravstvene kulture primijenio je upitnike tipa papir-olovka. Svi ispitanici imali su pismenu suglasnost roditelja da njihovo maloljetno dijete može ispunjavati upitnik. Svi ravnatelji škola dobili su pisanu molbu pa su odobrili provođenje upitnika.

Od statističkih postupaka korišteni su postupci za utvrđivanje osnovnih metrijskih značajki adaptiranih ljestvica za mjerenje motivacije $u$ nastavi Tjelesne $\mathrm{i}$ zdravstvene kulture: pouzdanost - Cronbach alpha; homogenost - analiza glavnih komponenti za svaku subljestvicu upitnika; osjetljivost - mjere središnjih vrijednosti, raspon rezultata, mjera odstupanja distribucije rezultata od normalne distribucije (Kolmogorov-Smirnovljev test), kao i mjere simetričnosti i oblika distribucije. Rezultati svih subljestvica dobiveni su tako da se rezultati svih negativno orijentiranih čestica rekodiraju u pozitivno orijentirane čestice, potom se rezultati svih čestica pojedine ljestvica zbroje i podijele $s$ brojem čestica iste ljestvice. Analizom glavnih komponenti (rotacija varimax; Guttman-Kaiserov kriterij za utvrđivanje broja značajnih komponenti) utvrđena je latentna struktura dimenzija motivacije mjerenih adaptiranim ljestvicama motivacije u nastavi Tjelesne i zdravstvene kulture. $\mathrm{Za}$ utvrđivanje razlika između učenica i učenika po izraženosti njihove motivacije za nastavni predmet Tjelesna i zdravstvena kultura primijenjen je t-test za nezavisne uzorke. Na kraju, za utvrđivanje razlika između skupina učenika različitih razina školskog postignuća (općeg uspjeha i uspjeha iz predmeta TZK), po njihovoj motivaciji za vježbanje u nastavi Tjelesne i zdravstvene kulture, primijenjena je diskriminacijska analiza. 


\section{Rezultati}

U tablici 1. prikazane su metrijske karakteristike ljestvica adaptiranog SMS upitnika za nastavu Tjelesne i zdravstvene kulture. Za procjenu pouzdanosti izračunat je Cronbach alpha koeficijent interne konzistencije. Za procjenu homogenosti, čestice pojedinih ljestvica projicirane su na faktore, za koje je izračunata objašnjena varijanca i njezin postotak. Osjetljivost je procijenjena primjenom KolmogorovSmirnovljeva testa, kao i analizom mjera oblika distribucije. Također su izračunati i osnovni deskriptivni pokazatelji (aritmetička sredina i standardna devijacija) ljestvica adaptiranog upitnika.

Tablica 1.

Uvidom u tablicu 1. može se uočiti da pouzdanost ljestvica varira u rasponu od $.58 \mathrm{za}$ ljestvicu eksternalne motivacije - introjicirane do .78 za ljestvicu unutrašnje motivacije - spoznati. Kod testova tipa „papir-olovka“ vrijednosti koeficijenta interne konzistencije manje od .60 smatraju se nedovoljno dobrima. Zbog toga je ljestvica eksternalne motivacije - introjicirane izostavljena iz daljnjih analiza. Također se može uočiti kako su sve ljestvice homogene jer su se njihove čestice projicirale u samo jednu zajedničku latentnu strukturu (jedan faktor), a ti faktori objašnjavaju između 44\% i $60 \%$ ukupne varijance čestica. Prema Kolomogorov-Smirnovljevu (K-S) testu, sve ljestvice (izuzev eksternalne motivacije - eksternalna regulacija) se značajno razlikuju od normalne distribucije. Međutim, treba napomenuti da je K-S test izuzetno osjetljiv na brojnost ispitanika i u uzorcima koji su veći od 200 konačni sud o osjetljivosti pojedinih ljestvica treba donijeti s obzirom na analizu mjera oblika distribucije. Svi koeficijenti zakrivljenosti i spljoštenosti manji su od 1, stoga je u daljnjoj obradi podataka moguće koristiti parametrijske statističke postupke. Prosjeci ljestvica variraju od najniže 2.05 za varijablu amotivacije, što pokazuje kako su učenici motivirani za nastavu Tjelesne i zdravstvene kulture, do najviše 3.69 za varijablu unutrašnje motivacije - ostvariti, što pokazuje kako su učenici najviše motivirani za to da u potpunosti savladaju određene radnje i vještine (motorička znanja) koje vježbaju i usvajaju pri izvođenju nastave Tjelesne i zdravstvene kulture.

\section{Rezultati komponentne analize}

$\mathrm{U}$ tablici 2. prikazani su rezultati faktorske analize (metoda glavnih komponenti) $\mathrm{u}$ varijablama za procjenu motivacije u nastavi Tjelesne i zdravstvene kulture. Za svaku komponentu prikazane su svojstvene vrijednosti (L) i postotci od ukupne varijance sustava varijabli (\%) posebno za učenice i učenike.

Tablica 2.

Promatrajući rezultate analize glavnih komponenti iz tablice 2., može se primijetiti da se mjere ljestvica motivacije za izvedbu nastave Tjelesne i zdravstvene kulture projiciraju u dvije komponente, kako na uzorku učenica, tako i na uzorka učenika. U 
oba uzorka obje komponente objašnjavaju ukupno po $76 \%$ ukupne varijance, a pritom prve komponente objašnjavaju više od 50\%, a drugi oko $20 \%$ ukupne varijance sustava. Projekcije pojedinih ljestvica upitnika na faktore također su vrlo slične u oba uzorka pa će se stoga ekstrahirani faktori interpretirati na isti način i za učenice i za učenike. Sve varijable, osim amotivacije kod učenika, amotivacije i eksternalne regulacije kod učenica, imaju visoke projekcije na prvi faktor. $S$ obzirom na to da najveće projekcije imaju varijable za procjenu unutrašnje motivacije, prvi faktor se interpretira kao unutrašnja motivacija. Zbog visokih projekcije ljestvica za procjenu amotivacije i eksternalne regulacije na drugi faktor on se interpretira kao amotivacija i eksternalna regulacija.

Osnovni deskriptivni pokazatelji varijabli, kao i analiza razlika u pojedinim varijablama motivacije po spolu, prikazani su u tablici 3. Razlike po spolu testirane su t-testom za nezavisne uzorke, s pripadajućim stupnjevima slobode i razinom značajnosti.

Tablica 3.

Analizom deskriptivnih pokazatelja može se zaključiti da su kod oba uzorka ispitanici najveće rezultate postigli u 3 ljestvice za procjenu unutrašnje motivacije, nešto niže vrijednosti u ljestvicama za procjenu vanjske motivacije, a najmanje u ljestvici za procjenu amotivacije. T-testom analizirana je značajnost razlika po spolu. Značajne razlike utvrđene su samo u 2 varijable koje se nalaze na zajedničkom faktoru amotivacija $i$ eksternalna regulacija. Pri tome su učenici imali značajno veće vrijednosti na obje ljestvice koje definiraju taj faktor. Učenice i učenici se ne razlikuju ni u jednoj mjeri za procjenu unutrašnje motivacije u nastavi Tjelesne i zdravstvene kulture.

U tablici 4. učenice i učenici podijeljeni su u 3 skupine s obzirom na opći uspjeh i uspjeh iz nastavnog predmeta Tjelesne i zdravstvene kulture. Hi-kvadrat testom analizirana je značajnost razlika učestalosti općeg uspjeha i uspjeha iz nastavnog predmeta Tjelesne i zdravstvene kulture u pojedinim skupinama po spolu.

\section{Tablica 4.}

Na temelju rezultata iz tablice 4. može se zaključiti kako se učenice i učenici značajno razlikuju po postotcima učestalosti svog akademskog postignuća i to u mjeri općeg uspjeha. Pri tome je kod učenika znatno veći postotak onih koji imaju opći uspjeh dobar i manji, a kod učenica je veći postotak onih s vrlo dobrim i s izvrsnim općim uspjehom. Za razliku od kriterija općeg uspjeha učenice i učenici se značajno ne razlikuju po učestalosti uspjeha iz nastavnog predmeta Tjelesne i zdravstvene kulture. Zbog tog nalaza, kao i zbog utvrđenih razlika u izraženosti mjera motivacije u nastavi Tjelesne i zdravstvene kulture, $\mathrm{u}$ daljnjoj obradi diskriminacijske analize zasebno su računate na uzorcima učenica i učenika. Na taj je način isključena mogućnost pripisivanja utvrđenih razlika motivacije u nastavi Tjelesne i zdravstvene kulture razlikama između spolova.

\section{Rezultati diskriminativne analize}

Rezultati diskriminativne analize djevojčica i dječaka različitog općeg uspjeha i različitog uspjeha iz nastavnog predmeta Tjelesne i zdravstvene kulture prikazani 
su u tablicama 5 i 6. Izračunata je svojstvena vrijednost diskriminativne funkcije $(\lambda)$, koeficijent kanoničke korelacije (Rc) i koeficijent Wilksova lambda (W入). Hi-kvadrat testom testirana je značajnost diskriminativne funkcije s pripadajućim stupnjevima slobode i razinom statističke značajnosti. Također su izračunati centroidi pojedinih skupina učenica i učenika, kao i projekcije pojedinih ljestvica na diskriminativnu funkciju (matrica strukture). Za svaku izračunatu diskriminativnu analizu u svakoj tablici prikazana je isključivo prva diskriminacijska funkcija jer druga diskriminacijska funkcija u svim provedenim analizama statistički nije značajna.

Tablica 5. -12 .

Iz tablica 5 do 8 može se uočiti da su dobivene značajne razlike u motivaciji za nastavni predmet Tjelesne i zdravstvene kulture učenica različitog općeg uspjeha, ali ne i učenika. Struktura diskriminativne funkcije i vrijednosti centroida grupa ukazuju na to da učenice s nižim općim uspjehom (dobar i manje i dijelom vrlo dobar) karakterizira viša izraženost eksternalne regulacije i više izražena amotiviranost $\mathrm{u}$ nastavi Tjelesne $\mathrm{i}$ zdravstvene kulture. Diskriminativna analiza nije pokazala razlike motivacije za nastavu Tjelesne i zdravstvene kulture kod skupina učenika različitog uspjeha iz nastavnog predmeta Tjelesna i zdravstvena kultura ni kod učenica, ni kod učenika (tablice 9 - 12).

\section{Rasprava i zaključci}

Metrijske karakteristike ljestvica (homogenost, pouzdanost i osjetljivost) upitnika adaptiranih za mjerenje motivacije u nastavi su dobre osim za ljestvicu introjekcije. Ljestvica introjekcije ima nedovoljnu razinu pouzdanosti, što se i moglo očekivati. Naime, autori upitnika SMS (Pelletier i sur., 1995) navode kako se prethodni eksternalni (izvanjski) motivacijski razlozi za sport tijekom dugotrajnog vježbanja postupkom introjekcije „mijenjaju“ i pritom postaju internalni (unutarnji) motivacijski razlozi. Opravdano je pretpostaviti kako kod učenika završnih razreda osnovne škole, zbog nedovoljno dugotrajnog bavljenja vježbanjem, postupak introjekcije mogućih izvanjskih motivacijskih razloga za vježbanje nije u potpunosti završen, nego je još u tijeku. Stoga i čestice kojima se ispituje eksternalna motivacija u nastavi Tjelesne i zdravstvene kulture tipa introjekcije ne mogu dostići dostatnu razinu za njezino kvalitetno mjerenje. Dakle, izuzev introjicirane eksternalne motivacije svi konstrukti motivacije za sport, uz određenu prilagodbu, primjenjivi su i na motivaciju u nastavi Tjelesne i zdravstvene kulture.

Latentna struktura motivacije u nastavi Tjelesne i zdravstvene kulture utvrdena na zasebnim uzorcima učenica i učenika pokazuje razliku od modela (Pelletier i sur., 1995) koji navodi kako postoje tri dimenzije motivacije za sport. Razlika se očituje $\mathrm{u}$ tome što se većina mjerenih varijabli motivacije u nastavi Tjelesne i zdravstvene kulture projicira u faktor internalne motivacije, a amotivacija i eksternalna regulacija su „spojeni” u zajednički faktor. Moguće je da se eksternalna motivacija ne diferencira $\mathrm{u}$ zasebnu dimenziju motivacije u nastavi Tjelesne i zdravstvene kulture za razliku od motivacije za sport, jer u nastavi Tjelesne i zdravstvene kulture ima puno manje prilika 
i mogućnosti za izvanjski utjecaj na sudionika vježbanja. Skupine vježbača u nastavi su brojnije, broj sati vježbanja u nastavi je manji nego u sportu, nastavnici nisu toliko orijentirani na sportsko postignuće vježbača kao treneri, nema natjecanja kakvih ima gotovo u svakom sportu i slično.

Amotivacija je najniže izražena od mjerenih varijabli i kod učenika i kod učenica, što pokazuje kako su učenici motivirani za vježbanje u nastavi Tjelesne i zdravstvene kulture. Eksterna regulacija (tj. ono što se uobičajeno i najčešće smatra eksternalnom motivacijom) najmanje je izražena i kod učenica i kod učenika u odnosu na sve ostale mjere ekstrinzične i intrinzične motivacije u nastavi Tjelesne i zdravstvene kulture. Mjere unutrašnje motivacije su više o odnosu na tu mjeru eksternalne motivacije. Razlike između učenika i učenica utvrđuju se u varijablama amotivacije i eksternalne regulacije, zasebnoj dimenziji motivacije u nastavi Tjelesne i zdravstvene kulture, što potvrđuje nalaz Maršića i sur. (2006) kako se po spolu učenika ne nalaze razlike u intrinzičnoj motivaciji, a utvrđene su u ekstrinzičnoj motivaciji. Učenici imaju više izraženu amotivaciju, ali im je viša i eksternalna regulacija od učenica, čime je ponovno potvrđen nalaz Maršića i sur. (2006).

Kod učenica i kod učenika redoslijed rangiranja mjera motivacije u nastavi TZK je vrlo sličan. U oba uzorka najizraženija je mjera unutrašnje motivacije potreba $z a$ savladavanjem - ostvariti što pokazuje internalnu motiviranost učenika završnih razreda osnovnih škola i njihovu „otvorenost” za usvajanje novih sadržaja na nastavi Tjelesne i zdravstvene kulture.

Mjere internalne motivacije su više od mjera eksternalne motivacije u nastavi Tjelesne i zdravstvene kulture u oba uzorka ispitanika. Taj nalaz o razlikama izraženosti internalne i eksternalne motivacije u nastavnom predmetu Tjelesna i zdravstvena kultura navodi na ideju (pomisao) o postajanju velike količine „rezervi” za izvanjsko motiviranje učenika za vježbanje tijekom nastave Tjelesne i zdravstvene kulture, kao i o potrebi da te „motivacijske rezerve” budu dopunjene dopunskim osposobljavanjem nastavnika/ učitelja Tjelesne i zdravstvene kulture.

Utvrđeni nalazi o razlikama jednog oblika akademskog postignuća (općeg uspjeha) pokazuju kako su učenice više motivirane za ostvarenje uspjeha u obrazovanju. Distribucije obje mjere akademskog postignuća su asimetrične. Također, u oba uzorka uspjeh iz nastavnog predmeta Tjelesne i zdravstvene kulture izrazito je negativno asimetričan, a u usporedbi s općim uspjehom istih uzoraka ima zamjetno veći postotak onih s visokim uspjehom. Zamijećene razlike u dvama mjerama akademskog postignuća moguće je pripisati većem broju razloga:

- opći uspjeh predstavlja kategorizirani prosjek ocjena iz svih nastavnih predmeta;

- predmet Tjelesna i zdravstvena kultura se u praksi nažalost često koristi kao predmet za podizanje prosjeka i time „poboljšavanje” općeg uspjeha učenika;

- nastavni predmet Tjelesna i zdravstvena kultura u nastavnoj praksi ocjenjuje se „stimulativno” pa tako, ako pojedinac i nema dovoljno izražene motoričke sposobnosti, ali ima usvojena motorička znanja, a podjednako sudjeluje u svim 
nastavnim sadržajima i aktivan je na satima Tjelesne i zdravstvene kulture, može zavrijediti visoku „stimulativnu” ocjenu;

- za upis u srednju školu se kao kriterij najčešće koriste mjere općeg uspjeha, a za to se nikada ne koristi predmet Tjelesna i zdravstvena kultura; zbog toga je moguće da su postignuća u predmetu Tjelesna i zdravstvena kultura „oslobođena” pritiska vrjednovanja.

Neovisno o razlozima zamjetnih razlika između dviju mjera akademskog postignuća ovaj nalaz dodatno otežava validaciju upitnika za mjerenje motivacije u nastavi Tjelesne i zdravstvene kulture.

Utvrđena značajnost razlika motivacije u nastavnom predmetu Tjelesna i zdravstvena kultura na uzorku učenica pokazuje kako učenice s nižim općim uspjehom imaju više izraženu dimenziju amotivacije i eksternalne regulacije. Skupine učenica različitog općeg uspjeha se vrlo malo razlikuju po svojoj internalnoj motivaciji. Razlozi za to mogu biti različiti, npr. povezanost niske motiviranosti učenica za postizanje općeg uspjeha s niskom motiviranošću za postignuće uspjeha nastavnog predmeta Tjelesna i zdravstvena kultura. Osim toga, takve učenice traže puno više izvanjskih motivacijskih poticaja i pozornosti od učitelja za svoj trud na nastavi Tjelesne i zdravstvene kulture, pa ako ih ne dobiju, onda su amotivirane za veći angažman. Nemogućnost prepoznavanja amotiviranih učenica zbog nastavnih obveza ili pak neosposobljenost pojedinih učitelja Tjelesne i zdravstvene kulture također može biti jedan od razloga.

Nasuprot tome, uspješnije učenice su općenito motiviranije, uvjerene su u svoje sposobnosti i kompetencije, ustrajne su u rješavanju i savladavanju zadataka, zbog čega imaju i niži stupanj amotiviranosti i eksternalne motivacije u nastavi Tjelesne i zdravstvene kulture. $\mathrm{U}$ uzorku učenika nisu utvrđene razlike motivacije u nastavi Tjelesne i zdravstvene kulture kod grupa učenika različitog općeg uspjeha.

Te nalaze o utvrđenoj značajnosti razlika motivacije kod učenica, kao i o nepostojanju razlika motivacije kod učenika, trebamo povezati s prethodno utvrđenim razlikama između učenika i učenica upravo u mjerama amotivacije i eksternalne regulacije. Povezavši ta dva nalaza, moguće je usporediti utvrđenu strukturu motivacije u nastavi tjelesne i zdravstvene kulture kod učenica s nižim općim uspjehom sa sličnom strukturom motivacije kakvu iskazuju učenici.

Diskriminativna analiza nije pokazala razlike u razini motivacije na nastavi Tjelesne i zdravstvene kulture ni kod učenica, ni kod učenika različitog uspjeha iz nastavnog predmeta Tjelesna i zdravstvena kultura. Nepostojanje značajnih razlika u motivaciji opravdano je pripisati strukturi distribucije uspješnosti iz nastavnog predmeta Tjelesna i zdravstvena kultura, koja nije diskriminativna jer vrlo velik postotak učenica i učenika ima najvišu ocjenu iz tog nastavnog predmeta, u obje skupine više od $70 \%$ učenika.

Kako bi se kvalitetno validirao adaptirani upitnik za mjerenje motivacije u nastavi Tjelesne i zdravstvene kulture, preporuča se u budućim istraživanjima: prvo, povećati broj ispitanika, kako u uzorku učenica, također i u uzorku učenika, kako bi se utvrđeni nalazi mogli kvalitetnije generalizirati; drugo, uključiti u istraživanje varijablu 
organiziranog bavljenja sportom učenika, kao i varijable kineziološke angažiranosti i percipirane sportske kompetencije - jer je moguće da učenici svoju višu eksternalnu regulaciju „donose” iz svog organiziranog bavljenja sportom ili zbog višeg stupnja svoje kineziološke angažiranosti; i treće, povezati rezultate motivacije učenica i učenika s uvjetima u kojima se provodi nastava Tjelesne i zdravstvene kulture - primjerice, postoji li mogućnost korištenja sportske dvorane i slično. Na kraju, vjerojatno bi motivacija u nastavi Tjelesne i zdravstvene kulture bila drukčije izražena ili pak strukturirana kad bi se povećao broj nastavnih sati za izvedbu nastave Tjelesne i zdravstvene kulture, što bi omogućilo kvalitetnije usvajanje motoričkih znanja, a time bi i odgovornost nastavnika Tjelesne i zdravstvene kulture za motiviranje učenika bila značajno veća.

Na kraju, može se zaključiti kako adaptirani upitnik za mjerenje motivacije u nastavi Tjelesne i zdravstvene kulture ima kvalitetne mjerne karakteristike izuzev ljestvice introjicirane eksternalne motivacije koja je izdvojena iz dopunskih analiza. Upitnik mjeri dvije latentne dimenzije motivacije: internalnu motivaciju i amotivaciju/eksternalnu regulaciju. Mjere internalne motivacije su zamjetno više od mjera amotivacije/eksternalne regulacije u oba uzorka. Učenici pokazuju značajno višu amotivaciju i eksternalnu regulaciju od učenica. U uzorku učenica učenice različitog općeg uspjeha se značajno razlikuju po skupu mjera motivacije, a posebno po dimenziji amotivacija/ eksternalna regulacija. Nije utvrđena značajna povezanost između uspjeha u predmetu Tjelesna i zdravstvena kultura sa skupom motivacijskih varijabli. Procjenjuje se kako adaptirani upitnik predstavlja kvalitetan instrument koji je u budućim istraživanjima potrebno dodatno validirati koristeći se dopunskom česticama i povećanim brojem ispitanika. Primjenom ovog upitnika nastavnici/učitelji Tjelesne i zdravstvene kulture mogu ispuniti više ciljeva: prvo, izmjeriti stanje motivacije u nastavi Tjelesne i zdravstvene kulture u pojedinom razrednom odjelu $u$ trenutku primjene i usporediti ga s rezultatima učenika dobivenih u ovom ili sličnom istraživanju; drugo, izmjeriti moguće promjene stanja motivacije razrednih odjela u nastavi Tjelesne i zdravstvene kulture između provedenog inicijalnog I finalnog mjerenja, koje mogu nastati zbog različitih materijalnih uvjeta rada, različitog osobnog angažmana nastavnika/učitelja Tjelesne i zdravstvene kulture u neposrednom radu s učenicima tijekom nastavne godine, kao i promjena u stupnju kineziološke angažiranosti učenika u izvannastavnim i izvanškolskim aktivnostima Također, preporuča se nastavnicima/učiteljima Tjelesne i zdravstvene kulture da posvete više pozornosti kvalitetnom komuniciranju s učenicima završnih razreda osnovnih škola, a time i kvalitetnijem utjecaju eksternalnog motiviranja učenika na izvedbu nastave Tjelesne i zdravstvene kulture. 